This document is confidential and is proprietary to the American Chemical Society and its authors. Do not copy or disclose without written permission. If you have received this item in error, notify the sender and delete all copies.

\title{
In situ biodegradation of phenanthrene in polycyclic aromatic hydrocarbon-contaminated sewage water revealed by coupling cultivation-dependent and -independent approaches
}

\begin{tabular}{|r|l|}
\hline Journal: & Environmental Science \& Technology \\
\hline Manuscript ID & es-2016-043669 \\
\hline Manuscript Type: & Article \\
\hline Complete List of Authors: & $\begin{array}{l}\text { Li, Jibing; Guangzhou Institute of Geochemistry, Chinese Academy of } \\
\text { Sciences; Graduate University of Chinese Academy of Sciences } \\
\text { song, mengke; Guangzhou Institute of Geochemistry, Chinese Academy of } \\
\text { Sciences } \\
\text { Dai, Qing; Guangzhou Institute of Geochemistry, Chinese Academy of } \\
\text { Sciences; Graduate University of Chinese Academy of Sciences } \\
\text { Jiang, Longfei; Guangzhou Institute of Geochemistry, Chinese Academy of } \\
\text { Sciences } \\
\text { Luo, Chunling; Guangzhou Institute of Geochemistry, Chinese Academy of } \\
\text { Sciences } \\
\text { Zhang, Dayi; Lancaster University, } \\
\text { Zhang, Gan; Guangzhou Institute of Geochsmistry, The Chinese Academy } \\
\text { of Sciences, State Key Laboratory of Organic Geochemistry }\end{array}$ \\
\hline
\end{tabular}


1

2

3

4

5 Jibing $\mathrm{Li}^{\dagger, *}$, Mengke Song ${ }^{\dagger}$, Qing Dai ${ }^{\dagger,}$, Longfei Jiang ${ }^{\dagger}$, Chunling Luo ${ }^{\dagger, *}$, Dayi Zhang ${ }^{\S}$, Gan

6 Zhang ${ }^{\dagger}$

7

8

9

10

11

12

13

14

15

In situ biodegradation of phenanthrene in polycyclic aromatic

hydrocarbon-contaminated sewage water revealed by coupling

cultivation-dependent and -independent approaches

${ }^{\dagger}$ Guangzhou Institute of Geochemistry, Chinese Academy of Sciences, Guangzhou 510640, China

${ }^{\ddagger}$ Graduate University of Chinese Academy of Sciences, Beijing, 100039, China

${ }^{\S}$ Lancaster Environment Centre, Lancaster University, Lancaster, LA1 4YQ, United Kingdom

*Corresponding authors: Dr. Chunling Luo

E-mail: clluo@gig.ac.cn

Tel.: +86-20-85290290; Fax: +86-20-85290706 
TOC

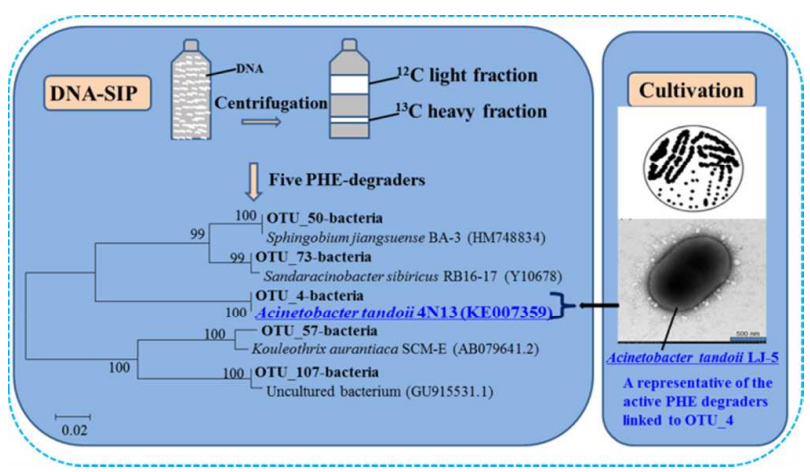




\section{ABSTRACT}

20 The microorganisms responsible for degrading phenanthrene (PHE) in polycyclic aromatic

21 hydrocarbon (PAH)-contaminated sewage water were identified by DNA-based stable isotope

22 probing (DNA-SIP). In addition to the well-known PHE degraders Acinetobacter and

23 Sphingobium, Kouleothrix, Sandaracinobacter and Kouleothrixaceae were found, for the first

24 time, to be directly responsible for in situ PHE biodegradation. Additionally, a novel PHE

25 degrader, Acinetobacter tandoii sp. LJ-5, was identified by DNA-SIP and direct cultivation. This

26 is the first report and reference to $A$. tandoii involved in the bioremediation of

27 PAH-contaminated water. A PAH-RHD gene involved in PHE metabolism was detected in the

DNA-SIP ${ }^{13} \mathrm{C}$ heavy fraction, but the amplification failed in A. tandoii LJ-5. Instead, the strain

29 contained catechol 1,2-dioxygenase and the alpha and beta subunits of protocatechuate

30 3,4-dioxygenase, indicating use of the $\beta$-ketoadipate pathway to degrade PHE and related

31 aromatic compounds. These findings add to our current knowledge on microorganisms that

32 degrade PHE by combining cultivation-dependent and cultivation-independent approaches and

33 provide deeper insight into the diversity of PHE-degrading communities in situ. 


\section{INTRODUCTION}

Polycyclic aromatic hydrocarbons (PAHs) are a group of hydrophobic organic compounds with fused aromatic rings that are generated from natural and anthropogenic processes and pose a serious threat to the health of all organisms. ${ }^{1,2}$ Because of their high toxicity, mutagenicity and carcinogenicity, the United States Environmental Protection Agency has classified PAHs as priority pollutants since the $1970 \mathrm{~s}^{3}{ }^{3}$ Bioremediation has proven to be a cost-effective and environmentally friendly alternative to removing PAHs from contaminated sites. ${ }^{4,5}$

Considerable effort based on traditional cultivation-dependent approaches has focused on isolating and identifying cultivable PAH degraders to explore the fate of PAHs. Hitherto, many microorganisms capable of degrading PAHs have been isolated and evaluated, most of which belong to the genera Agmenellum, Aeromonas, Alcaligenes, Acinetobacter, Arthrobacter, Bacillus, Berjerinckia, Burkholderia, Comamonas, Corynebacterium, Cyclotrophicus, Flavobacterium, Moraxella, Micrococcus, Mycobacterium, Marinobacter, Nocardioides, Pasteurella, Pseudomonas, Lutibacterium, Rhodococcus, Streptomyces, Stenotrophomonas, Sphingomonas, Vibrio and Paenibacillus. ${ }^{6-17}$ Cultivation-based approaches provide clues about PAH degraders and PAH degradation pathways. Furthermore, functional genes associated with PAH degradation, such as PAH-ring hydroxylating dioxygenases (PAH-RHDs) ${ }^{18,19}$ and PAH-ring cleaving dioxygenases (PAH-RCDs), including catechol dioxygenase $[\mathrm{CAT}]^{20,21}$ and protocatechuate dioxygenase $[\mathrm{PACH}])^{22-24}$, have been identified. However, it is difficult to obtain all PAH-degrading isolates in nature, as the majority of microbes are uncultivable, ${ }^{25}$ and cultivation-based methods greatly underestimate prokaryotic diversity. ${ }^{26}$ In addition, cultivation-based method fails to explain the complex interactions among individuals within 
microbial communities in their native environment. ${ }^{27}$

Cultivation-independent methods, which can be used to effectively evaluate the prokaryotic diversity of complex systems, ${ }^{28,29}$ have been used to evaluate microbial degradation of PAHs. ${ }^{30-33}$ High-throughput methods have revolutionised the ability to investigate deeper into the microbial communities contained in environmental samples by providing higher resolution of microbial taxa compared with that of conventional cloning techniques. ${ }^{34}$ However, these methods fail to accurately identify the metabolic or functional features of the targeted microorganisms. ${ }^{34}$ Stable-isotope probing (SIP) is a cultivation-independent technique that circumvents the requirement of distinguishing organisms to assess metabolic responses and links identity to function. $^{35}$ It has been successfully used in environmental samples by feeding microbial communities stable isotope-labelled substrates $\left({ }^{13} \mathrm{C}\right.$ or $\left.{ }^{15} \mathrm{~N}\right)$ to label the intracellular components (DNA, RNA, or proteins) and allowing the separation and characterisation of the targeted but hidden functional microorganisms according to buoyancy, particularly those not amenable to cultivation. ${ }^{17}$ To date, SIP has been used to identify a large number of PAH-degrading bacteria. $^{27,32,33,36}$

Phenanthrene (PHE) is a common PAH model compound used in biodegradation studies due to its ubiquity in nature and its fused-ring angular structure. ${ }^{13,17}$ A number of in situ PAH degraders have been identified in real-world habitats, such as soil or seawater, using the DNA-SIP method. ${ }^{27,31,36-38}$ However, only a few investigators have successfully isolated the microbes using traditional cultivation methods, ${ }^{31}$ which help determine their metabolic characteristics and explore the functional populations actually responsible for pollutant degradation in the field. In the present study, DNA-SIP was applied to sewage water samples to link the bacterial taxa with their PHE 
87

biodegradation phenotypes in situ. In addition, cultivation-based and high-throughput techniques were used to achieve a more thorough understanding of the bacterial communities contributing to PHE degradation. Here, a representative active PHE degrader (Acinetobacter tandoii LJ-5) was successfully isolated from the microbial sewage community. We focused on the functional genes involved in PHE metabolism to explore the environmental significance of this strain. The functional genes encoding PAH-RHD and PAH-RCD (CAT and PACH) were investigated by analysing relevant sequences amplified from the ${ }^{13} \mathrm{C}$-DNA-enriched fraction and A. tandoii LJ-5 DNA. In this study, the PHE-degrading bacteria in sewage water was successfully characterised using DNA-SIP and cultivation-based methods. We hope to provide novel information on the bioremediation of PAH-contaminated sites using a reliable theoretical basis. 


\section{MATERIALS AND METHODS}

2.1. Sample collection. Water samples were collected from sewage at an oil refinery $\left(37^{\circ} 49^{\prime} \mathrm{N}, 118^{\circ} 25^{\prime} \mathrm{E}\right.$; altitude, $\left.37.49 \mathrm{~m}\right)$ located in Shandong Province, China. After transport to the laboratory, a portion of the samples was stored at $-20^{\circ} \mathrm{C}$ for subsequent DNA extraction. The remaining samples were immediately stored at $4{ }^{\circ} \mathrm{C}$ for PHE degradation and SIP experiments. The PAHs identified in the sewage water are listed in Table S1 (determined using gas chromatography-mass spectrometry as described below).

\subsection{SIP experiment}

2.2.1. SIP microcosms. A $50 \mathrm{~mL}$ water sample was placed in a $150 \mathrm{~mL}$ serum bottle. Unlabelled PHE (99\%; Cambridge Isotope Laboratories, Inc., Tewksbury, MA, USA) or

${ }^{13} \mathrm{C}$-labeled PHE $\left({ }^{13} \mathrm{C}_{6}\right.$-PHE, 99\%; Cambridge Isotope Laboratories, Inc.) at a final concentration of $10 \mathrm{mg} / \mathrm{L}$ was added to a bottle with a rubber stopper and an aluminium cap using a gas-tight syringe. Microcosms without PHE were used as the non-PHE control, and those with unlabelled PHE in filter-sterilised sewage water were used as the sterile control. Each treatment was conducted in triplicate. All microcosms were incubated in the dark with shaking at $120 \mathrm{rpm}$ and room temperature $\left(\sim 25^{\circ} \mathrm{C}\right)$. The serum bottles were opened each day for approximately $1 \mathrm{~h}$ to maintain the ambient oxygen level. On day 3 of incubation, samples from each treatment were removed for PHE analysis and DNA extraction.

2.2.2. Nucleic acid extraction and ultracentrifugation. After centrifuging $100 \mathrm{~mL}$ of each water sample from the ${ }^{12} \mathrm{C}$-PHE and ${ }^{13} \mathrm{C}$-PHE treatments, total nucleic acids were extracted from the resulting cell pellets using the PowerSoil DNA Isolation Kit (MO BIO, Carlsbad, CA, USA) according to the manufacturer's instructions. ${ }^{39}$ DNA content was quantified using the ND-2,000 
110

111

112

113

114

115

116

117

118

119

120

121

122

123

124

UV-Vis spectrophotometer (NanoDrop Technologies, Wilmington, DE, USA).

Approximately $5 \mu \mathrm{g}$ DNA were added to Quick-Seal polyallomer tubes $(13 \times 51 \mathrm{~mm}, 5.1 \mathrm{~mL}$;

Beckman Coulter, Pasadena, CA, USA) and mixed with Tris-EDTA ( $\mathrm{pH} \mathrm{8.0)-CsCl} \mathrm{solution} \mathrm{at} \mathrm{a}$ final buoyant density (BD) of $\sim 1.77 \mathrm{~g} / \mathrm{mL}$. The BD was determined using a digital refractometer (model AR200; Leica Microsystems Inc., Buffalo Grove, IL, USA). After balancing and sealing, the tubes were transferred to an ultracentrifuge (Optima L-100XP, Beckman Coulter) at 45,000 g $\left(20^{\circ} \mathrm{C}\right)$ for $48 \mathrm{~h}$. Subsequently, DNA in the tube was fractioned (400 $\mu \mathrm{L}$ each) and collected using a fraction recovery system (Beckman Coulter). After the BD measurements, the DNA fractions were purified using the method described by Sun et al. ${ }^{40}$ The relationships between BD and the fraction number or DNA concentration are listed in Figure S1 and Figure S2, respectively.

\subsubsection{High-throughput sequencing and computational analyses. Sequencing was} conducted using an Illumina MiSeq sequencer with the standard pipeline. The V4 hypervariable region of bacterial $16 \mathrm{~S}$ rRNA in fractions from samples derived from the ${ }^{12} \mathrm{C}-\mathrm{PHE}$ and ${ }^{13} \mathrm{C}-\mathrm{PHE}$ microcosms was amplified using the F515/R806 primer set (Table 1), with a sample-specific 12-bp barcode added to the reverse primer as described by Liu et al. ${ }^{41}$ Reads were filtered if they contained primer mismatches, uncorrectable barcodes or ambiguous bases. Then, the qualified sequences were analysed using the MOTHUR software package. ${ }^{42,43}$ Sequences were assigned using an operational taxonomic unit (OTU)-based method to generate microbiome profiles. $^{44-46}$

The relative abundance of each OTU was determined as described previously. ${ }^{40}$ In total, 4,186 OTUs were detected in all samples, and those with the top 100 relative abundances were selected for analysis. Bacteria represented by OTUs that were enriched in the heavy fractions 
132

from ${ }^{13} \mathrm{C}$-PHE samples compared with ${ }^{12} \mathrm{C}$-PHE samples were identified as PHE degraders. Finally, five OTUs (OTU_4, OTU_50, OTU_57, OTU_73 and OTU_107) were selected and aligned to Acinetobacter spp., Sphingobium spp., Kouleothrix spp., Sandaracinobacter spp. and Kouleothrixaceae spp. (accession numbers: KX364043-KX364047), respectively, using the Greengenes database. ${ }^{47,48}$ The phylogenetic information from the sequences was analysed using the Basic Local Alignment Search Tool algorithm (National Center for Biotechnology Information, Bethesda, MD, USA) and MEGA ver. $4.0{ }^{49}$

2.3. Isolation of PHE degraders by enrichment and cultivation. Raw sewage water (5 $\mathrm{mL}$ ) was added to $50 \mathrm{~mL}$ minimal medium $(\mathrm{MM})$ (Table $\mathrm{S} 3, \mathrm{pH}=7.0$ ) with $1,000 \mathrm{mg} / \mathrm{L}$ PHE (MM-P) as the carbon source. After a $25^{\circ} \mathrm{C}$ incubation for 7 days, $5 \mathrm{~mL}$ of the culture medium were subcultured in $50 \mathrm{~mL}$ fresh MM-P medium and incubated under the same conditions for another 7 days. After three sequential rounds of enrichment, the enriched population was serially diluted and spread on MM-P agar. The plates were incubated at $25^{\circ} \mathrm{C}$ for 4 days. In total, 10 colonies were isolated, purified and identified. The growth curve was calculated, and the PHE degradation efficiency of the isolated strain was evaluated in MM supplemented with different concentrations of PHE $(100-1,000 \mathrm{mg} / \mathrm{L})$ in the dark for 7 days on a $180 \mathrm{rpm}$ shaking plate at $30^{\circ} \mathrm{C}$. PHE degradation was determined using the method described in Section 2.5. Genomic DNA was extracted, and the 16S rRNA gene sequence was amplified by polymerase chain reaction (PCR) using the $27 \mathrm{f}$ and $1492 \mathrm{r}$ bacterial universal primers (Table 1). ${ }^{50}$ In addition, the morphological and physiological characteristics, GC content and DNA-DNA hybridisation of the isolated strain were determined using previously described methods. ${ }^{51}$ Cell counts were adjusted to approximately $1 \times 10^{7}$ colony forming units $/ \mathrm{mL}$ at the beginning of the experiment 
154

155

156

157

158

159

160

161

162

163

164

165

166

167

168

169

170

171

172

173

174

175

using the dilution plate counting method. ${ }^{52}$ Cell growth was evaluated by measuring the optical density of the culture at $600 \mathrm{~nm}$. Controls without cells were also established. All tests were performed in triplicate, using the same standard and incubation conditions as those used for the microcosm experiment.

2.4. Detection of PAH-RHD and PAH-RCD genes. The PAH-RHD $\mathrm{P}_{\alpha}$ gene in the heavy DNA fraction was investigated in Gram positive and Gram negative (GN) degraders using two primer sets, $642 \mathrm{f} / 933 \mathrm{r}^{53}$ and $610 \mathrm{f} / 911 \mathrm{r}^{53}$, respectively (Table 1). Gradient PCR was performed at annealing temperatures of $52-62^{\circ} \mathrm{C} .{ }^{54}$ However, only the PAH-RHD $\alpha$ GN primer set produced a specific amplicon and was selected for this study. The amplification reactions were conducted according to previous methods. ${ }^{54}$ The PAH-RCD genes (CAT and PACH) were amplified using the CAT1f/CAT1r, CAT2f/CAT2r, PACH1f/PACH1r and PACH2f/PACH2r primer pairs listed in Table 1. All specific primer sets were designed based on published sequences of $A$. tandoii DSM $14970^{\mathrm{T}}$ (GenBank assembly accession number: GCA_000400735.1) using Primer Premier 5.0 software. The CAT1f/CAT1r and CAT2f/CAT2r primer pairs were used to target two different types of CATA. The PCR program for these two primer sets was as follows: 3 min at $95^{\circ} \mathrm{C} ; 32$ cycles of $95^{\circ} \mathrm{C}$ for $30 \mathrm{~s}, 52^{\circ} \mathrm{C}$ for $30 \mathrm{~s}$ and $72^{\circ} \mathrm{C}$ for $55 \mathrm{~s}$; final extension at $72^{\circ} \mathrm{C}$ for $5 \mathrm{~min}$. The PACH1f/PACH1r and PACH2f/PACH2r primer pairs were used to target the alpha and beta subunits of PACH, respectively. The PCR program for PACH1f/PACH1r and PACH2f/PACH2r was as follows: $3 \mathrm{~min}$ at $95^{\circ} \mathrm{C} ; 32$ cycles of $95^{\circ} \mathrm{C}$ for $30 \mathrm{~s}, 52^{\circ} \mathrm{C}$ for $30 \mathrm{~s}$ and $72^{\circ} \mathrm{C}$ for $40 \mathrm{~s}$; final extension at $72^{\circ} \mathrm{C}$ for $5 \mathrm{~min}$. The PCR products were gel-purified using a gel extraction kit (D2500-01; Omega Bio-tek, Norcross, GA, USA), followed by cloning and sequencing as described by Song et al. ${ }^{55}$ The phylogenetic dendrograms were prepared using the method 
176

177

178

179

180

181

182

183

184

185

186

187

188

189

190

191

192

described above.

The partial PAH-RHD and PAH-RCD gene sequences obtained are available in GenBank under the following accession numbers: KX364042 for PAH-RHD, KX364048 and KX364049 for CATA and KX364050 and KX364051 for PACH. The GenBank accession number for the 16S rRNA gene obtained from isolated A. tandoii is KU168603.

2.5. PHE analysis. The PHE concentrations in each microcosm treatment were analysed on days 0 and 3 as follows. The water sample was spiked with 1,000 ng deuterated PAHs as a surrogate standard and was extracted twice with dichloromethane (DCM). The extracted organic phase was concentrated to approximately $0.5 \mathrm{~mL}$ after solvent exchange with hexane and then purified using a silica gel/alumina column ( $8 \mathrm{~mm}$ i.d.) filled with anhydrous $\mathrm{Na}_{2} \mathrm{SO}_{4}(1 \mathrm{~cm})$, neutral silica gel ( $3 \mathrm{~cm}, 3 \%$ deactivated) and neutral alumina ( $3 \mathrm{~cm}, 3 \%$ deactivated) from top to bottom, using $15 \mathrm{~mL}$ hexane/DCM $(1: 1, \mathrm{v} / \mathrm{v})$ as the eluent. After concentrating the eluent to approximately $50 \mu \mathrm{L}$ using a gentle stream of $\mathrm{N}_{2}, 1,000 \mathrm{ng}$ hexamethylbenzene were added as an internal standard to all samples before the instrumental analysis.

PHE was analysed by gas chromatography (model 7890; Agilent Technologies, Santa Clara, CA, USA), using a capillary column (DB-5MS; $30 \mathrm{~m} \times 0.25 \mathrm{~mm}, 0.25 \mu \mathrm{m}$ ) and a mass spectrometric detector (model 5975; Agilent) as described by Jiang et al. ${ }^{17}$ 
193

194

195

196

197

198

199

200

201

202

203

204

205

206

207

208

209

210

211

212

213

214

\section{RESULTS}

3.1 PHE biodegradation in sewage water. PHE biodegradation in the ${ }^{12} \mathrm{C}-\mathrm{PHE}$ and ${ }^{13}$ C-PHE microcosms is shown in Table S2. The PHE concentration in the sterile treatment exhibited fewer decreases than those in the biotic treatments. Residual PHE was $11-13 \%$ and $12-13 \%$ in the ${ }^{12} \mathrm{C}-\mathrm{PHE}$ and ${ }^{13} \mathrm{C}-\mathrm{PHE}$ microcosms, respectively, suggesting that significant PHE biodegradation occurred in the biotic treatments. No difference $(p>0.05)$ was observed between the ${ }^{12} \mathrm{C}$-PHE and ${ }^{13} \mathrm{C}$-PHE treatments, consistent with our previous study. ${ }^{55}$

3.2. Bacteria involved in PHE degradation as revealed by DNA-SIP. DNA extracted from the ${ }^{12} \mathrm{C}$-PHE and ${ }^{13} \mathrm{C}$-PHE microcosms was subjected to ultracentrifugation and fractionation, followed by high-throughput sequencing of each fraction. The relative abundance of $16 \mathrm{~S}$ rRNA defined by the family taxon showed no difference in the microbial communities between the samples from the ${ }^{12} \mathrm{C}-\mathrm{PHE}$ and ${ }^{13} \mathrm{C}-\mathrm{PHE}$ treatments (Figure S3).

The organisms responsible for ${ }^{13} \mathrm{C}$ assimilation were detected during screening by comparing the relative abundances of specific OTUs between the ${ }^{12} \mathrm{C}$-PHE and ${ }^{13} \mathrm{C}$-PHE samples from each fraction. The results indicated that OTU_4 at a higher BD $(>1.7209 \mathrm{~g} / \mathrm{mL})$ was enriched only in the ${ }^{13} \mathrm{C}$-PHE sample, but not in the ${ }^{12} \mathrm{C}$-PHE sample (Figure 1). Additionally, the relative abundances of OTU_50, OTU_73, OTU_57 and OTU_107 at higher BDs $(>1.7209,>1.7296$, $1.7122-1.7481$ and $1.7209-1.7481 \mathrm{~g} / \mathrm{mL}$, respectively) were also higher in the ${ }^{13} \mathrm{C}-\mathrm{PHE}$ samples than in the ${ }^{12} \mathrm{C}-\mathrm{PHE}$ samples. The higher abundance in the heavier fraction indicates that organisms represented by OTU_4, OTU_50, OTU_73, OTU_57 and OTU_107 play a primary role in PHE degradation.

Figure 2 shows phylogenetic information for the PHE degraders represented by the above 
215

216

217

218

219

220

221

222

223

224

225

226

227

228

229

OTUs. OTU_4 belonging to the genus Acinetobacter (phylum Proteobacteria, class Gammaproteobacteria, order Pseudomonadales, family Moraxellaceae) shared 100\% similarity with strains $A$. tandoii DSM $14970^{\mathrm{T}}$ (KE007359), Acinetobacter parvus DSM $16617^{\mathrm{T}}$ (AIEB01000124), Acinetobacter beijerinckii CIP 110307 ${ }^{\mathrm{T}}$ (APQL01000005), Acinetobacter tjernbergiae DSM $14971^{\mathrm{T}}$ (ARFU01000016) and Acinetobacter haemolyticus CIP $64.3^{\mathrm{T}}$ (APQQ01000002) and formed a subclade with a high bootstrap value of 97. OTU_50 and OTU_73 were assigned to the genera Sphingobium and Sandaracinobacter within the same family Sphingomonadaceae (phylum Proteobacteria, class Alphaproteobacteria, order Sphingomonadales), and they shared 100\% similarity with Sphingobium jiangsuense BA-3T (HM748834) and 99\% similarity with Sandaracinobacter sibiricus RB16-17 ${ }^{\mathrm{T}}$ (Y10678), respectively. OTU_57 and OTU_107 were classified in the genus Kouleothrix (phylum Chloroflexi, class Chloroflexi, order Roseiflexales, family Kouleothrixaceae) and family Kouleothrixaceae (genus unclassified), respectively. OTU_57 shared 97\% similarity with Kouleothrix aurantiaca SCM-E (AB079641.2) and formed a subclade with a high bootstrap value of 100 .

3.3. Presence of the PAH-RHDa genes in the SIP fractions. The PAH-RHD $\alpha$ genes from GN bacteria were analysed in the heavy fractions $\left({ }^{13} \mathrm{C}\right.$-labeled DNA, marked with a star in Figure 1). In the present study, only one $\mathrm{PAH}-\mathrm{RHD}_{\alpha} \mathrm{GN}$ gene was detected, affiliated with the PAH-RHD $\alpha$ (PhnAc) gene from Delftia acidovorans Eh2-1 clone 5 (AY367788.1) (Figure 3).

3.4. Isolation and characterisation of PHE-degrading bacteria. We isolated PHE degraders from sewage water to characterise the bacteria corresponding to the five SIP-identified OTUs. Of all PHE-degrading isolates, only one bacterial strain, named $A$. tandoii LJ-5, was identified in 
237

contaminated sewage water samples after PHE enrichment. This strain shared $100 \%$ similarity with the OTU_4 sequence and was therefore representative of the active PHE degraders linked to OTU_4. However, no strains belonging to the other four SIP-identified OTUs were successfully isolated from sewage water.

A. tandoii LJ-5 is a GN, rod-shaped, obligate aerobe lacking flagella, with a size of $(0.7-1.0) \times$ (1.0-1.5) $\mu \mathrm{m}$ (Figure 4). The A. tandoii LJ-5 colonies were circular, smooth, convex and white pigmented with a colony diameter of $0.5-2.0 \mathrm{~mm}$ after growth on MM-P agar plates at $30^{\circ} \mathrm{C}$ for 48 h. A. tandoii LJ-5 grew under different conditions, including 0-3\% (w/v) salinity (optimum 0\%), $\mathrm{pH} 5.0-9.0$ (optimum $\mathrm{pH}=7.0$ ) and temperatures of $25-40^{\circ} \mathrm{C}$ (optimum $30^{\circ} \mathrm{C}$ ) (Figure $\mathrm{S} 4$ ). The metabolic characteristics of $A$. tandoii LJ-5 are listed in Table S4. A. tandoii LJ-5 had the highest $16 \mathrm{~S}$ rRNA gene sequence similarity to that of $A$. tandoii DSM $14970^{\mathrm{T}}$ (KE007359) (97.77\%), whereas its similarity levels to other Acinetobacter strains were $<97.0 \%$. A. tandoii LJ-5 belongs to the genus Acinetobacter according to the neighbour-joining (Figure S5) phylogenetic dendrograms based on 16S rRNA gene sequences, and it formed a subclade with $A$. tandoii DSM $14970^{\mathrm{T}}$. The GC content of $A$. tandoii LJ-5 was $41.0 \mathrm{~mol} \%$, which was within the range of that of other Acinetobacter spp. (38.1-54.7 mol\%). The DNA-DNA hybridisation value for $A$. tandoii LJ-5 with $A$. tandoii DSM $14970^{\mathrm{T}}$ was $90.11 \pm 0.8 \%$, which was significantly above the threshold value of $70 \%{ }^{56}$ Taken together, these results indicate that $A$. tandoii LJ-5 belongs to the species $A$. tandoii.

As shown in Figure S6, A. tandoii LJ-5 grew well in MM-P with PHE concentrations of 100$1,000 \mathrm{mg} / \mathrm{L}$ under optimal growing conditions (pH 7.0 and $30^{\circ} \mathrm{C}$ ), suggesting strong tolerance of $A$. tandoii LJ-5 to high PHE concentrations. More than $60 \%$ of the PHE was biodegraded within 7 
259

260

261

262

263

264

265

266

267

268

269

270

271

272

273

days at all PHE concentrations. Enrichment of Acinetobacter (OUT_4) was detected in the

${ }^{13} \mathrm{C}-\mathrm{PHE}$ treatment, indicating that $A$. tandoii LJ-5 is a major PHE degrader in situ.

3.5. Presence of PHE metabolism-related genes in A. tandoii LJ-5. To further explore the environmental significance of $A$. tandoii LJ-5, we evaluated its functional genes involved in PHE metabolism. Although one PAH-RHD ${ }_{\alpha}$ GN gene was detected in the heavy fraction of the ${ }^{13} \mathrm{C}-\mathrm{PHE}$ sample, no PAH-RHD $\alpha$ gene was successfully amplified from $A$. tandoii $\mathrm{LJ}-5$ using the same primer set. However, the genes encoding CATA-1 and CATA-2 and the alpha and beta subunits of PACH-1 and PACH-2 were identified in A. tandoii LJ-5 in this study.

The CATA-1 (KX364048) and CATA-2 (KX364049) translated amino acid sequences showed high homology with that of CATA from Acinetobacter junii (WP_004961950.1, 92\%) and Acinetobacter schindleri (WP 004809441.1. 93\%), respectively, as illustrated in Figure 5a. Figure 5b shows the high homologies of A. tandoii LJ-5 PACH-1 (KX364050) and PACH-2 (KX364051) at the amino acid level compared with the alpha subunit of PACH from Acinetobacter bouvetii DSM 14963 (WP_005011151.1, 99\%) and the beta subunit of PACH from Acinetobacter johnsonii XBB1 (WP_058952216.1,99\%). 
274

275

276

277

278

279

280

281

282

283

284

285

286

287

\section{DISCUSSION}

Some studies have successfully applied DNA-SIP in the detection of indigenous microorganisms

involved in PHE biodegradation..$^{27,36-38}$ Our study employed DNA-SIP and identified five OTUs directly responsible for in situ PHE biodegradation, such as the phylotypes affiliated with Acinetobacter, Sphingobium, Kouleothrix, Sandaracinobacter and Kouleothrixaceae (genus unclassified) from PAH-contaminated sewage water.

The genus Sphingobium was first described by Takeuchi, ${ }^{57}$ and 41 species in this genus have been isolated and reported (http://www.bacterio.cict.fr/s/sphingobium.html). Sphingobium is a well-known PAH-degrading genus in the family Sphingomonadaceae. ${ }^{57,58}$ Some strains in this genus metabolise a wide range of PAHs, such as naphthalene, PHE, anthracene, fluoranthene, pyrene and benzo[a]pyrene. ${ }^{59-63}$ However, no study has used SIP to demonstrate the in situ PHE-degradation capacity of Sphingobium. The genus Sandaracinobacter also belongs to the family Sphingomonadaceae. Until now, only one species (Sandaracinobacter sibiricus) has been isolated and reported in this genus. ${ }^{64}$ The phylogenetic analysis of SIP-identified OTU_73 suggests its close relationship to S. sibiricus RB16-17 ${ }^{\mathrm{T}}$ (Figure 2). S. sibiricus is an obligate aerobic phototrophic bacterium that contains bacteriochlorophyll $a$, which is light-harvesting complex II and the reaction centre. ${ }^{64}$ This bacterium tolerates and reduces high levels of tellurite. ${ }^{64}$ However, this strain has not been linked previously to PHE degradation; thus, our present results provide strong evidence that some microbes in this genus are primarily responsible for in situ PHE degradation in sewage water.

The phylogenetic analysis of the microorganisms represented by OTU_57 suggested their close relationship to Kouleothrix aurantiaca SCM-E (Figure 2). K. aurantiaca SCM-E was first 
296

297

298

299

300

301

302

303

304

305

306

307

308

309

310

311

312

313

314

315

316

317

isolated by Kohno from activated industrial waste sludge. ${ }^{65}$ The genus Kouleothrix belongs to phylum Chloroflexi (family Kouleothrixaceae, class Chloroflexi), which is one of the earliest diverging lineages of bacteria and was first defined by Garrity and Holt in Bergey's Manual of Systematic Bacteriology. ${ }^{66}$ Class Chloroflexi is one of at least five major Kouleothrix subgroups, and all known species in this class have a multicellular filamentous morphology. ${ }^{67} \mathrm{~A}$ number of studies have indicated that microorganisms in the phylum Chloroflexi are closely related to PAH degradation. Shahi et al. showed that $\gamma$-Proteobacteria, Chloroflexi, Firmicutes and $\delta$-Proteobacteria were the most dominant bacterial phyla in petroleum-contaminated soil from a coastal site at an old petroleum sludge storage pit in Turkey. ${ }^{68}$ Bacterial species belonging to $\gamma$-Proteobacteria, $\delta$-Proteobacteria and Chloroflexi change dramatically after treatment with PAHs, indicating that PAHs play key roles in bacterial community diversity. ${ }^{69}$ Muangchinda et al. reported that indigenous microbes from the phylum Chloroflexi degrade PAHs and provided bioremediation information for Antarctic soils and sediments, ${ }^{70}$ although PAH contaminants such as PHE and pyrene decrease the abundance of Chloroflexi during PAH remediation. ${ }^{71,72}$ However, Kouleothrix and Kouleothrixaceae have not been linked previously to PHE metabolism; thus, it is unclear whether these microbes are directly involved in PHE degradation. Our results provide unequivocal evidence that some microorganisms in these taxa are primarily responsible for in situ PHE degradation in the complex microbial community of PAH-contaminated sewage water.

Acinetobacter, belonging to $\gamma$-Proteobacteria and to the order Pseudomonadales, is a GN, non-motile and strictly aerobic bacteria. These bacteria are widespread in natural environments, including hydrocarbon-contaminated sites. ${ }^{73,74}$ Members of Acinetobacter possess versatile metabolic capabilities, such as pathways for degrading aromatic and hydroxylated aromatic 
318

compounds. $^{75}$ Since the early days of taxonomic research, the ability to degrade aromatic compounds has been a common characteristic used to identify microbes in the genus Acinetobacter. ${ }^{9,75,76}$ Hereinto, some strains metabolise PAHs, such as POHE, acenaphthene and pyrene. ${ }^{77-80}$ Degradation of PHE by Acinetobacter has not been identified using DNA-SIP prior to this study. Our results demonstrate that $A$. tandoii LJ-5 metabolises PHE in situ. A. tandoii was first described by Emma et al. in 2003 but was not previously associated with PAH degradation. ${ }^{81}$

Our results provide $A$. tandoii LJ-5 reference data for application to PAH-contaminated sewage water treatment.

The presence of the distinctive $\mathrm{PAH}^{-\mathrm{RHD}_{\alpha}} \mathrm{GN}$ gene in the heavy DNA fraction from the ${ }^{13} \mathrm{C}$-PHE microcosm suggests its functionality associated with PHE-degrading strains of Acinetobacter, Sphingobium, Kouleothrix, Sandaracinobacter and Kouleothrixaceae, as identified by DNA-SIP. Failure to amplify this $\mathrm{PAH}-\mathrm{RHD}_{\alpha}$ gene from $A$. tandoii LJ-5 might be attributed to 1) incompatibility of the primers used in this study with the functional genes present in this PHE degrader or 2) a different PHE degradation mechanism present in A. tandoii LJ-5. Acinetobacter genes that catabolise aromatic compounds are enriched in five genomic loci within $25 \%$ of the genome, ${ }^{82}$ whereas the metabolic genes of other aromatic compound degraders, such as microbes in the genus Sphingomonas or Pseudomonas, are scattered throughout their genome. ${ }^{83,84}$ The mechanism is unclear, but some preliminary evidence suggests that syntenic localisation of the genes associated with this metabolic pathway relieves the energy burden on the transcriptional and translational machinery. ${ }^{85}$ Metabolism of many aromatic compounds produces the intermediate metabolites catechol and protocatechuate via the $\beta$-ketoadipate pathway. In the present study, we found that $A$. tandoii LJ-5 expresses genes involved in two parallel branches of the $\beta$-ketoadipate 
340 (ortho) pathway (CATA and PACH). ${ }^{86}$ The presence of PACH suggests that A. tandoii LJ-5

341 degrades PAHs and related aromatic compounds via the ortho-cleavage pathway for compounds

342 funnelled through protocatechuate (via PACH). ${ }^{22}$ Successful amplification of CATA also indicates

343 that $A$. tandoii LJ-5 metabolises catechol through the catechol branch of the ortho-cleavage

344 pathway. ${ }^{87}$ Previous studies have suggested that the CATA route is preferred under

345 low-contamination conditions. ${ }^{88,89}$ The presence of ortho-cleavage for catechol probably helped $A$.

346 tandoii LJ-5 adapt to the low levels of PAHs in the present PAH-contaminated sewage water.

347 This is the first study to apply a culture-independent DNA-SIP technique to identify the

348 bacterial taxa responsible for PHE degradation in PAH-contaminated sewage. The results provide

349 unequivocal evidence that Acinetobacter, Sphingobium, Kouleothrix, Sandaracinobacter and

350 Kouleothrixaceae are involved in in situ biodegradation of PHE in sewage, none of which has

351 been previously reported as a PHE-degrading microorganism using SIP. Sandaracinobacter,

352 Kouleothrix and Kouleothrixaceae have not been previously linked to PHE degradation.

353 Moreover, given that few bacteria linked to in situ PHE metabolism have been isolated from

354 real-world habitats, ${ }^{31}$ this study identified A. tandoii LJ-5 as a PHE degrader by DNA-SIP and

355 identified its functions by characterising its functional PHE metabolic genes and pathways. This is

356 the first report of a role for $A$. tandoii in bioremediation of PAH-contaminated water. These results

357 expand our current knowledge on microorganisms that degrade PHE by combining both

358 cultivation-dependent and cultivation-independent approaches. 
359 The English in this document has been checked by at least two professional editors, both native

360 speakers of English. For a certificate, please see:

361 http://www.textcheck.com/certificate/IcBnHE

362

363

ACKNOWLEDGMENTS

364 Financial support was provided by the National Natural Science Foundation of China (No.

365 41322008) and the Doctoral Scientific Research Foundation of Guangdong Province (No.

366 2016A030310118). 
367

368

369

370

371

372

373

374

375

376

377

\section{REFERENCES}

(1) Baek, S. O.; Field, R. A.; Goldstone, M. E.; Kirk, P. W.; Lester, J. N.; Perry, R. A review of atmospheric polycyclic aromatic hydrocarbons: Sources, fate and behavior. Water, Air, Soil Poll. 1991, 60 (3), 279-300.

(2) Xue, W.; Warshawsky, D. Metabolic activation of polycyclic and heterocyclic aromatic hydrocarbons and DNA damage: a review. Toxicol. Appl. Pharm. 2005, 206 (1), 73-93.

(3) Keith, L.; Telliard, W. Priority pollutants Ia perspective view. Environ. Sci. Technol. 197913 (4), 416-423.

(4) Harayama, S. Polycyclic aromatic hydrocarbon bioremediation design. Curr. Opin. Biotech. 1997, $8(3), 268-273$.

(5) Wilson, S. C., Kevin C. Jones Bioremediation of soil contaminated with polynuclear aromatic hydrocarbons (PAHs): a review. Environ. Pollut. 1993, 81 (3), 229-249.

(6) Daane, L.; Harjono, I.; Barns, S.; Launen, L.; Palleron, N.; Häggblom, M. PAH-degradation by Paenibacillus spp. and description of Paenibacillus naphthalenovorans sp. nov., a naphthalene-degrading bacterium from the rhizosphere of salt marsh plants. Int. J. Syst. Evol Micr. 2002, 52 (1), 131-139.

(7) Juhasz, A. L.; Britz, M.; Stanley, G. Degradation of fluoranthene, pyrene, benz[a]anthracene and dibenz[a,h]anthracene by Burkholderia cepacia. J. Appl Microbiol. 1997, 83 (2), 189-198.

(8) Juhasz, A. L.; Stanley, G. A.; Britz, M. L. Microbial degradation and detoxification of high molecular weight polycyclic aromatic hydrocarbons by Stenotrophomonas maltophilia strain VUN 10,003. Lett. Appl. Microbiol. 2000, 30 (5), 396-401. 
389

(9) Jung, J.; Park, W. Acinetobacter species as model microorganisms in environmental microbiology: current state and perspectives. Appl. Microbiol. Biot. 2015, 99 (6), 2533-2548.

(10) Kim, J. D.; Shim, S. H.; Lee, C. G. Degradation of phenanthrene by bacterial strains isolated from soil in oil refinery fields in Korea. J. Microbiol. Biotech. 2005, 15 (2), 337-345.

(11) Lease, C. W.; Bentham, R. H.; Gaskin, S. E.; Juhasz, A. L. Isolation and identification of pyrene mineralizing Mycobacterium spp. from contaminated and uncontaminated sources. Appl. Environ. Soil Sci. 2011, 2011, 1457-1463.

(12) Samanta, S. K.; Singh, O. V.; Jain, R. K. Polycyclic aromatic hydrocarbons: environmental pollution and bioremediation. Trends Biotechnol. 2002, 20 (6), 243-248.

(13) Seo, J. S.; Keum, Y. S.; Li, Q. X. Bacterial degradation of aromatic compounds. Inter. J. Env. Res. Pub. Heal. 2009, 6 (1), 278-309.

(14) Van Hamme, J. D.; Singh, A.; Ward, O. P. Recent advances in petroleum microbiology. Microbiol. Mol. Biol. R. 2003, 67 (4), 503-549.

(15) Wong, J.; Lai, K.; Wan, C.; Ma, K.; Fang, M. Isolation and optimization of PAH-degradative bacteria from contaminated soil for PAHs bioremediation. Water, Air, Soil Poll. 2002, 139 $(1-4), 1-13$.

(16) Zhao, H. P.; Wang, L.; Ren, J. R.; Li, Z.; Li, M.; Gao, H. W. Isolation and characterization of phenanthrene-degrading strains Sphingomonas sp. ZP1 and Tistrella sp. ZP5. J. Hazard. Mater. 2008, $152(3), 1293-1300$.

(17) Jiang, L.; Song, M.; Luo, C.; Zhang, D.; Zhang, G. Novel phenanthrene-degrading bacteria identified by DNA-stable isotope probing. Plos one 2015, 10 (6), e 0130846.

(18) Cebron, A.; Louvel, B.; Faure, P.; France-Lanord, C.; Chen, Y.; Murrell, J. C.; Leyval, C. 
Root exudates modify bacterial diversity of phenanthrene degraders in PAH-polluted soil but not phenanthrene degradation rates. Environ. Microbiol. 2011, 13 (3), 722-736.

(19) Moser, R.; Stahl, U. Insights into the genetic diversity of initial dioxygenases from PAH-degrading bacteria. Appl. Microbiol. Biot. 2001, 55 (5), 609-618.

(20) Cebron, A.; Beguiristain, T.; Bongoua-Devisme, J.; Denonfoux, J.; Faure, P.; Lorgeoux, C.; Ouvrard, S.; Parisot, N.; Peyret, P.; Leyval, C. Impact of clay mineral, wood sawdust or root organic matter on the bacterial and fungal community structures in two aged PAH-contaminated soils. Environ. Sci. Pollut. R. 2015, 22 (18), 13724-13738.

(21) Peng, R. H.; Xiong, A. S.; Xue, Y.; Fu, X. Y.; Gao, F.; Zhao, W.; Tian, Y. S.; Yao, Q. H. Microbial biodegradation of polyaromatic hydrocarbons. FEMS Microbiol. Rev. 2008, 32 (6), $927-955$.

(22) Thomas, F.; Lorgeoux, C.; Faure, P.; Billet, D.; Cébron, A. Isolation and substrate screening of polycyclic aromatic hydrocarbon degrading bacteria from soil with long history of contamination. Int. Biodeter. Biodegr. 2016, 107, 1-9.

(23) Ohlendorf, D. H.; Weber, P. C.; Lipscomb, J. D. Determination of the quaternary structure of protocatechuate 3,4-dioxygenase from Pseudomonas aeruginosa. J.Mol. Biol. 1987, 195 (1), $225-227$.

(24) Zaborsky, O. R.; Schwartz, R. D. The effect of imidoesters on the protocatechuate 3,4-dioxygenase activity of Acinetobacter calcoaceticus. Febs Lett. 1974, 46 (1), 236-238.

(25) Amann, R. I.; Ludwig, W.; Schleifer, K. H. Phylogenetic identification and in situ detection of individual microbial cells without cultivation. Microbiol. Rev. 1995, 59 (59), 143-169.

(26) Oren, A. Prokaryote diversity and taxonomy: current status and future challenges. Philos. T. 
R. Soc. B. 2004, 359 (1444), 623-638.

(27) Jones, M. D.; Crandell, D. W.; Singleton, D. R.; Aitken, M. D. Stable-isotope probing of the polycyclic aromatic hydrocarbon-degrading bacterial guild in a contaminated soil. Environ. Microbiol. 2011, 13 (10), 2623-2632.

(28) Breznak, J. A. A need to retrieve the not-yet-cultured majority. Environ. Microbiol. 2002, 4 $(1), 4-5$.

(29) Rappé, M. S.; Giovannoni, S. J. The Uncultured Microbial Majority. Annu. Rev. Microbiol. 2003, 57 (1), 369-394.

(30) Huang, W. E.; Ferguson, A.; Singer, A. C.; Lawson, K.; Thompson, I. P.; Kalin, R. M.; Larkin, M. J.; Bailey, M. J.; Whiteley, A. S. Resolving genetic functions within microbial populations: in situ analyses using rRNA and mRNA stable isotope probing coupled with single-cell raman-fluorescence in situ hybridization. Appl. Environ. Microb. 2009, 75 (1), 234-241.

(31) Jeon, C. O.; Park, W.; Padmanabhan, P.; DeRito, C.; Snape, J. R.; Madsen, E. L. Discovery of a bacterium, with distinctive dioxygenase, that is responsible for in situ biodegradation in contaminated sediment. P. Natl. Acad. Sci. USA. 2003, 100 (23), 13591-13596.

(32) Jones, M. D.; Singleton, D. R.; Carstensen, D. P.; Powell, S. N.; Swanson, J. S.; Pfaender, F. K.; Aitken, M. D. Effect of incubation conditions on the enrichment of pyrene-degrading bacteria identified by stable-isotope probing in an aged, PAH-contaminated soil. Microb. Ecol. 2008, 56 (2), 341-349.

(33) Singleton, D. R.; Hunt, M.; Powell, S. N.; Frontera-Suau, R.; Aitken, M. D. Stable-isotope probing with multiple growth substrates to determine substrate specificity of uncultivated bacteria. J. Microbiol. Meth. 2007, 69 (1), 180-187. 
455

456

457

458

459

460

461

462

463

464

465

466

467

468

469

470

471

472

473

474

475

476

(34) Gutierrez, T. Identifying polycyclic aromatic hydrocarbon-degrading bacteria in oil-contaminated surface waters at Deepwater Horizon by cultivation, stable isotope probing and pyrosequencing. Rev. Environ. Sci. Bio. 2011, 10 (4), 301-305.

(35) Dumont, M. G.; Murrell, J. C. Stable isotope probing-linking microbial identity to function. Nat. Rev. Microbiol. 2005, 3 (6), 499-504.

(36) Gutierrez, T.; Singleton, D. R.; Berry, D.; Yang, T.; Aitken, M. D.; Teske, A. Hydrocarbon-degrading bacteria enriched by the Deepwater Horizon oil spill identified by cultivation and DNA-SIP. ISME J. 2013, 7 (11), 2091-2104.

(37) Martin, F.; Torelli, S.; Paslier, D. L.; Barbance, A.; Martin-Laurent, F.; Bru, D.; Geremia, R.; Blake, G.; Jouanneau, Y. Betaproteobacteria dominance and diversity shifts in the bacterial community of a PAH-contaminated soil exposed to phenanthrene. Environ. Pollut. 2012, 162 (162), 345-353.

(38) Regonne, R. K.; Martin, F.; Mbawala, A.; Ngassoum, M. B.; Jouanneau, Y. Identification of soil bacteria able to degrade phenanthrene bound to a hydrophobic sorbent in situ. Environ. Pollut. 2013, 180, 145-151.

(39) Tillett, D.; Neilan, B. A. Xanthogenate nucleic acid isolation from cultured and environmental cyanobacteria. J. Phycol. 2000, 36 (1), 251-258.

(40) Sun, W.; Xie, S.; Luo, C.; Cupples, A. M. Direct link between toluene degradation in contaminated-site microcosms and a Polaromonas strain. Appl. Environ. Microb. 2010, 76 (3), 956-959.

(41) Liu, J.; Hua, Z. S.; Chen, L. X.; Kuang, J. L.; Li, S. J.; Shu, W. S.; Huang, L. N. Correlating microbial diversity patterns with geochemistry in an extreme and heterogeneous environment 
of mine tailings. Appl. Environ. Microb. 2014, 80 (12), 3677-3686.

(42) Schloss, P. D.; Westcott, S. L.; Ryabin, T.; Hall, J. R.; Hartmann, M.; Hollister, E. B.; Lesniewski, R. A.; Oakley, B. B.; Parks, D. H.; Robinson, C. J. Introducing mothur: open-source, platform-independent, community-supported software for describing and comparing microbial communities. Appl. Environ. Microb. 2009, 75 (23), 7537-7541.

(43) Caporaso, J. G.; Kuczynski, J.; Stombaugh, J. QIIME allows analysis of high-throughput community sequencing data. Nat. Methods 2010, 7 (5), 335-336.

(44) Edgar, R. C. Search and clustering orders of magnitude faster than BLAST. Bioinformatics 2010, 26 (19), 2460-2461.

(45) Mcdonald, D.; Price, M. N.; Goodrich, J.; Nawrocki, E. P.; Desantis, T. Z.; Probst, A.; Andersen, G. L.; Knight, R.; Hugenholtz, P. An improved Greengenes taxonomy with explicit ranks for ecological and evolutionary analyses of bacteria and archaea. ISME J. 2012, 6 (3), 610-618.

(46) Werner, J. J.; Koren, O.; Hugenholtz, P.; Desantis, T. Z.; Walters, W. A.; Caporaso, J. G.; Angenent, L. T.; Knight, R.; Ley, R. E. Impact of training sets on classification of high-throughput bacterial 16s rRNA gene surveys. ISME J. 2012, 6 (1), 94-103.

(47) Caporaso, J. G.; Bittinger, K.; Bushman, F. D.; Desantis, T. Z.; Andersen, G. L.; Knight, R. PyNAST: a flexible tool for aligning sequences to a template alignment. Bioinformatics 2009, $26(2), 266-267$.

(48) Desantis, T. Z.; Hugenholtz, P.; Larsen, N.; Rojas, M.; Brodie, E. L.; Keller, K.; Huber, T.; Dalevi, D.; Andersen, P. H. L. Greengenes, a chimera-checked 16S rRNA gene database and workbench compatible with ARB. Appl. Environ. Microb. 2006, 72 (7), 5069-5072. 
499

500

501

502

503

504

505

506

507

508

509

510

511

512

513

514

515

516

517

518

519

520

(49) Tamura, K.; Dudley, J.; Nei, M.; Kumar, S. MEGA4: Molecular Evolutionary Genetics Analysis (MEGA) software version 4.0. Mol. Biol. Evol. 2007, 24 (8), 1596-1599.

(50) Baker, G.; Smith, J. J.; Cowan, D. A. Review and re-analysis of domain-specific 16S primers. J. Microbiol. Meth. 2003, 55 (3), 541-555.

(51) Li, J.; Lu, Q.; Liu, T.; Zhou, S.; Yang, G.; Zhao, Y. Paenibacillus guangzhouensis sp. nov., an Fe (III)-and humus-reducing bacterium from a forest soil. Int. J. Syst. Evol. Micr. 2014, 64 (11), 3891-3896.

(52) Li, J.; Lin, T.; Lu, Q.; Wang, J. J.; Liao, C.; Pan, Y.; Zhao, Y. Changes in physicochemical properties and bactericidal efficiency of acidic electrolyzed water ice and available chlorine decay kinetics during storage. LWT-Food Sci. Technol. 2014, 59 (1), 43-48.

(53) Mu, D. Y.; Scow, K. M. Effect of trichloroethylene (TCE) and toluene concentrations on TCE and toluene biodegradation and the population density of TCE and toluene degraders in soil. Appl. Environ. Microb. 1994, 60 (7), 2661-2665.

(54) Cebron, A.; Norini, M. P.; Beguiristain, T.; Leyval, C. Real-Time PCR quantification of PAH-ring hydroxylating dioxygenase (PAH-RHDalpha) genes from Gram positive and Gram negative bacteria in soil and sediment samples. J. Microbiol. Meth. 2008, 73 (2), 148-159.

(55) Song, M.; Luo, C.; Jiang, L.; Zhang, D.; Wang, Y.; Zhang, G. Identification of benzo[a]pyrene-metabolizing bacteria in forest soils by using DNA-based stable-isotope probing. Appl. Environ. Microb. 2015, 81 (21), 7368-7376.

(56) Wayne, L. G.; Brenner, D. J.; Colwell, R. R.; Grimont, P. A. D.; Kandler, O. International Committee on Systematic Bacteriology. Report of the ad hoc committee on reconciliation of approaches to bacterial systematics. Int. J. Syst. Bacteriol. 1987, 37, 463-464. 
521 (57) Takeuchi, M.; Hamana, K.; Hiraishi, A. Proposal of the genus Sphingomonas sensu stricto

522

523

524

525 and three new genera, Sphingobium, Novosphingobium and Sphingopyxis, on the basis of phylogenetic and chemotaxonomic analyses. Int. J. Syst. Evol. Micr. 2001, 51 (4), $1405-1417$.

(58) Busse, H. J.; Denner, E. B.; Buczolits, S.; Salkinoja-Salonen, M.; Bennasar, A.; Kampfer, P. Sphingomonas aurantiaca sp. nov., Sphingomonas aerolata sp. nov. and Sphingomonas faeni sp. nov., air- and dustborne and Antarctic, orange-pigmented, psychrotolerant bacteria, and emended description of the genus Sphingomonas. Int. J. Syst. Evol. Micr. 2003, 53 (5), $1253-1260$.

(59) Kim, S. J.; Chun, J.; Bae, K. S.; Kim, Y. C. Polyphasic assignment of an aromatic-degrading Pseudomonas sp., strain DJ77, in the genus Sphingomonas as Sphingomonas chungbukensis sp. nov. Int. J. Syst. Evol. Micr. 2000, 50 (4), 1641-1647.

(60) Shin, H. J.; Kim SJKim, Y. C. Sequence analysis of the phnD gene encoding 2-hydroxymuconic semialdehyde hydrolase in Pseudomonas sp. strain DJ77. Biochem. Bioph. Res. Co. 1997, $232(2), 288-291$.

(61) Colombo, M.; Cavalca, L.; Bernasconi, S.; Andreoni, V. Bioremediation of polyaromatic hydrocarbon contaminated soils by native microflora and bioaugmentation with Sphingobium chlorophenolicum strain C3R: A feasibility study in solid- and slurry-phase microcosms. Int. Biodeter. Biodegr. 2011, 65 (1), 191-197.

(62) Pal, R.; Bala, S.; Dadhwal, M.; Kumar, M.; Dhingra, G.; Prakash, O.; Prabagaran, S. R.; Shivaji, S.; Cullum, J.; Holliger, C.; Lal, R. Hexachlorocyclohexane-degrading bacterial strains Sphingomonas paucimobilis B90A, UT26 and $\mathrm{Sp}+$, having similar lin genes, represent 
three distinct species, Sphingobium indicum sp. nov., Sphingobium japonicum sp. nov. and Sphingobium francense sp. nov., and reclassification of Sphingomonas chungbukensis as Sphingobium chungbukense comb. nov. Int. J. Syst. Evol. Micr. 2005, 55 (5), 1965-1972.

(63) Pinyakong, O.; Habe, H.; Yoshida, T.; Nojiri, H.; Omori, T. Identification of three novel salicylate 1-hydroxylases involved in the phenanthrene degradation of Sphingobium sp. strain P2. Biochem. Bioph. Res. Co. 2003, 301 (2), 350-357.

(64) Yurkov, V.; Stackebrandt, E.; Buss, O.; Vermeglio, A.; Gorlenko, V.; Beatty, J. T. Reorganization of the genus Erythromicrobium: Description of "Erythromicrobium sibiricum" as Sandaracinobacter sibiricus gen. nov., sp. nov., and of "Erythromicrobium ursincola" as Erythromonas ursincola gen. nov., sp. nov. Int. J. Syst. Evol. Micr. 1997, 47 (4), 1172-1178.

(65) Kohno, T.; Sei, K.; Mori, K. Characterization of type 1851 organism isolated from activated sludge samples. Water Sci. Technol. 2002, 46 (1-2), 111-114.

(66) Garrity, G. M.; Holt, J. G.; Castenholz, R. W.; Pierson, B. K.; Keppen, O. I.; Gorlenko, V. M. Phylum BVI. Chloroflexi phy. nov. 2001; pp 427-446.

(67) Hugenholtz, P.; Stackebrandt, E. Reclassification of Sphaerobacter thermophilus from the subclass Sphaerobacteridae in the phylum Actinobacteria to the class Thermomicrobia (emended description) in the phylum Chloroflexi (emended description). Int. J. Syst. Evol. Micr. 2004, 54 (6), 2049-2051.

(68) Shahi, A.; Aydin, S.; Ince, B.; Ince, O. Evaluation of microbial population and functional genes during the bioremediation of petroleum-contaminated soil as an effective monitoring approach. Ecotox. Environ. Safe. 2016, 125, 153-160.

(69) Zhang, X. Z.; Xie, J. J.; Sun, F. L. Effects of three polycyclic aromatic hydrocarbons on 
sediment bacterial community. Curr. Microbiol. 2014, 68 (6), 756-762.

(70) Muangchinda, C.; Chavanich, S.; Viyakarn, V.; Watanabe, K.; Imura, S.; Vangnai, A. S.; Pinyakong, O. Abundance and diversity of functional genes involved in the degradation of aromatic hydrocarbons in Antarctic soils and sediments around Syowa Station. Environ. Sci. pollut. R. 2015, 22 (6), 4725-4735.

(71) Ren, G.; Ren, W.; Teng, Y.; Li, Z. Evident bacterial community changes but only slight degradation when polluted with pyrene in a red soil. Front. Microbiol. 2015, 6, 22.

(72) Su, J.; Ouyang, W.; Hong, Y.; Liao, D.; Khan, S.; Li, H. Responses of endophytic and rhizospheric bacterial communities of salt marsh plant (Spartina alterniflora) to polycyclic aromatic hydrocarbons contamination. J. Soil. Sediment. 2015, 16 (2), 707-715.

(73) Mahjoubi, M.; Jaouani, A.; Guesmi, A.; Amor, S. B.; Jouini, A.; Cherif, H.; Najjari, A.; Boudabous, A.; Koubaa, N.; Cherif, A. Hydrocarbonoclastic bacteria isolated from petroleum contaminated sites in Tunisia: isolation, identification and characterization of the biotechnological potential. New Biotechnol. 2013, 30 (6), 723-733.

(74) Kostka, J. E.; Om, P.; Overholt, W. A.; Green, S. J.; Gina, F.; Andy, C.; Jonathan, D.; Nikita, N.; Hazen, T. C.; Markus, H. Hydrocarbon-degrading bacteria and the bacterial community response in gulf of Mexico beach sands impacted by the deepwater horizon oil spill. Appl. Environ. Microb. 2011, 77 (22), 7962-7974.

(75) Yoshida, S.; Tazaki, K.; Minamikawa, T. Occurrence of shikimic and quinic acids in angiosperms. Phytochemistry 1975, 14 (14), 195-197.

(76) Simarro, R.; González, N.; Bautista, L. F.; Molina, M. C. Biodegradation of high-molecular-weight polycyclic aromatic hydrocarbons by a wood-degrading consortium at 
low temperatures. Fems Microbiol. Ecol. 2013, 83 (2), 438-449.

(77) Ghosal, D.; Dutta, A.; Chakraborty, J.; Basu, S.; Dutta, T. K. Characterization of the metabolic pathway involved in assimilation of acenaphthene in Acinetobacter sp. strain AGAT-W. Res. Microbiol. 2013, 164 (2), 155-163.

(78) Shao, Y.; Wang, Y.; Wu, X.; Xu, X.; Kong, S.; Tong, L.; Jiang, Z.; Li, B. Biodegradation of PAHs by Acinetobacter isolated from karst groundwater in a coal-mining area. Environ. Earth Sci. 2015, 73 (11), 7479-7488.

(79) Yuan, H.; Yao, J.; Masakorala, K.; Wang, F.; Cai, M.; Yu, C. Isolation and characterization of a newly isolated pyrene-degrading Acinetobacter strain USTB-X. Environ. Sci. pollut. R. 2014, 21 (4), 2724-2732.

(80) Zhao, Z.; Selvam, A.; Wong, J. W. Synergistic effect of thermophilic temperature and biosurfactant produced by Acinetobacter calcoaceticus BU03 on the biodegradation of phenanthrene in bioslurry system. J. Hazard. Mater. 2011, 190 (1-3), 345-350.

(81) Carr, E. L.; Kämpfer, P.; Patel, B. K.; Gürtler, V.; Seviour, R. J. Seven novel species of Acinetobacter isolated from activated sludge. Int. J. Syst. Evol. Micr. 2003, 53 (4), 953-963.

(82) Barbe, V.; Vallenet, D.; Fonknechten, N.; Kreimeyer, A.; Oztas, S.; Labarre, L.; Cruveiller, S.; Robert, C.; Duprat, S.; Wincker, P.; Ornston, L. N.; Weissenbach, J.; Marliere, P.; Cohen, G. N.; Medigue, C. Unique features revealed by the genome sequence of Acinetobacter sp. ADP1, a versatile and naturally transformation competent bacterium. Nucleic Acids Res. 2004, $32(19)$, 5766-5779.

(83) Pinyakong, O.; Habe, H.; Omori, T. The unique aromatic catabolic genes in sphingomonads degrading polycyclic aromatic hydrocarbons (PAHs). J. Gen. Appl. Microbiol. 2003, 49 (1), 
609

610

611

612

613

614

615

616

617

618

619

620

621

622

623

624

625

$1-19$.

(84) Jiménez, J. I.; Miñambres, B.; García, J. L.; Díaz, E. Genomic analysis of the aromatic catabolic pathways from Pseudomonas putida KT2440. Environ. Microbiol. 2002, 4 (12), $824-841$.

(85) Jung, J.; Park, W. Acinetobacter species as model microorganisms in environmental microbiology: current state and perspectives. Appl. Microbiol. Biot. 2015, 99 (6), 2533-2548.

(86) Fuchs, G.; Boll, M.; Heider, J. Microbial degradation of aromatic compounds from one strategy to four. Nat. Rev. Microbiol. 2011, 9 (11), 803-816.

(87) Romeroarroyo, C. E.; Schell, M. A.; Gaines, G. L.; Neidle, E. L. catM encodes a LysR-type transcriptional activator regulating catechol degradation in Acinetobacter calcoaceticus. J. Bacteriol. 1995, 177 (20), 5891-5898.

(88) Ampe, F.; Lindley, N. D. Flux limitations in the ortho pathway of benzoate degradation of Alcaligenes eutrophus: metabolite overflow and induction of the meta pathway at high substrate concentrations. In Microbiology, 1996; pp 1807-1817.

(89) Sei, K.; Inoue, D.; Wada, K.; Mori, K.; Ike, M.; Kohno, T.; Fujita, M. Monitoring behaviour of catabolic genes and change of microbial community structures in seawater microcosms during aromatic compound degradation. Water Res. 2005, 38 (20), 4405-4414. 
626

627

628

629

630

631

632

633

634

635

636

637

638

639

640

641

642

643

644

645

646

647

\section{Captions}

Figure 1 The shift tendency of OTU_4, OTU_50, OTU_73, OTU_57 and OTU_107 fragments. The relative abundance of the OTU_4, OTU_50, OTU_73, OTU_57 and OTU_107 fragments over a range of buoyant density (BD) from DNA extracted from the sewage water added with either ${ }^{12} \mathrm{C}$ - or ${ }^{13} \mathrm{C}$-labeled PHE after 3 days of incubation.

Figure 2 Phylogenetic tree of identified OTUs responsible for in situ PHE degradation. Neighbour-joining tree based on 16S rRNA gene sequences showing the phylogenetic position of the bacteria corresponding OTU_4, OTU_50, OTU_57, OTU_73, OTU_107 and their representatives of some other related taxa. Bootstrap values (expressed as percentages of 1200 replications) $>50 \%$ are shown at the branch points. Bar 0.02 substitutions per nucleotide position.

Figure 3 Phylogenetic tree of amplified $\mathrm{PAH}-\mathrm{RHD}_{\alpha}$ GN gene from heavy fraction in ${ }^{13} \mathrm{C}-\mathrm{PHE}$ microcosm. PAH-RHD gene showed 97\% similarity with Delftia acidovorans Eh2-1 clone 5 PhnAc gene.

Figure 4 (a) Isolated A. tandoii LJ-5 colonies on MM-P agar plate; (b) Transmission electron micrograph of $A$. tandoii LJ-5 cells. Bar, $500 \mathrm{~nm}$ (left) and $1000 \mathrm{~nm}$ (right).

Figure 5 Phylogenetic tree based of CATA and PACH sequences from strain LJ-5. (a) High homology at amino acid level (92\% and 93\%) was detected with catechol 1,2-dioxygenase of Acinetobacter junii (WP_004961950.1) and Acinetobacter schindleri (WP_004809441.1), respectively. (b) High homology at amino acid level (99\% and 99\%) was detected with subunit alpha of protocatechuate 3,4-dioxygenase of Acinetobacter bouvetii DSM 14963 (WP_005011151.1), and subunit beta of protocatechuate 3,4-dioxygenase of Acinetobacter johnsonii XBB1 (WP_058952216.1), respectively. 
648 Table 1 Primers used for the PCR of 16S rRNA, PAH-RHD and PAH-RCD gene.

\begin{tabular}{|c|c|c|}
\hline Targets & Primer & Sequence $\left(5^{\prime}-3^{\prime}\right)$ \\
\hline \multirow{4}{*}{ 16S rRNAs } & $515 f$ & GTGCCAGCMGCCGCGGTAA \\
\hline & $806 \mathrm{r}$ & AACGCACGCTAGCCGGACTACVSGGGTATCTAAT \\
\hline & $27 \mathrm{f}$ & AGAGTTTGATCCTGGCTCAG \\
\hline & $1492 \mathrm{r}$ & GGTTACCTTGTTACGACTT \\
\hline \multirow{4}{*}{ PAH-RHD } & $610 \mathrm{f}$ & GAGATGCATACCACGTKGGTTGGA \\
\hline & $911 \mathrm{r}$ & AGCTGTTGTTCGGGAAGAYWGTGCMGTT \\
\hline & $641 \mathrm{f}$ & CGGCGCCGACAAYTTYGTNGG \\
\hline & $933 \mathrm{r}$ & GGGGAACACGGTGCCRTGDATRAA \\
\hline \multirow{8}{*}{ PAH-RCD } & CAT1f & ATGTCGATACCGCACAAGGA \\
\hline & CAT1r & TGCACGACGACGATCAACT \\
\hline & CAT2f & CGCGACGACGATCTACTTCA \\
\hline & CAT2r & CTGCAACTGGTCCTGTCGAT \\
\hline & PACH1f & ACGCACAACGCAATACCGAT \\
\hline & PACH1r & ACGACCACGCAAAGTGATGT \\
\hline & $\mathrm{PACH} 2 \mathrm{f}$ & TGAAACTCCATCTCAAACAGGTG \\
\hline & $\mathrm{PACH} 2 \mathrm{r}$ & ACTGTTTCGTCTTCGCCTTGT \\
\hline
\end{tabular}


$650 \quad$ Figure 1

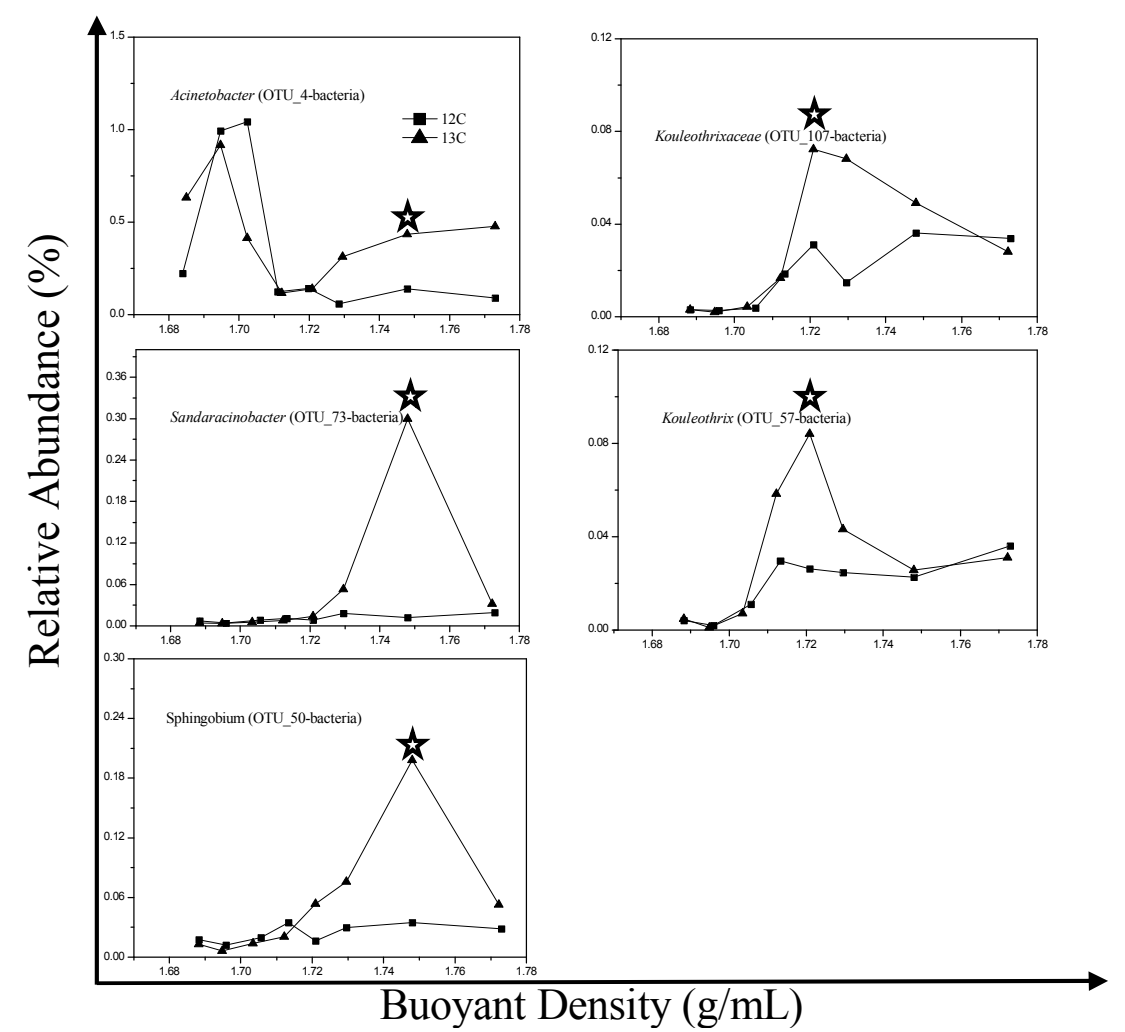

651

652 
$653 \quad$ Figure 2

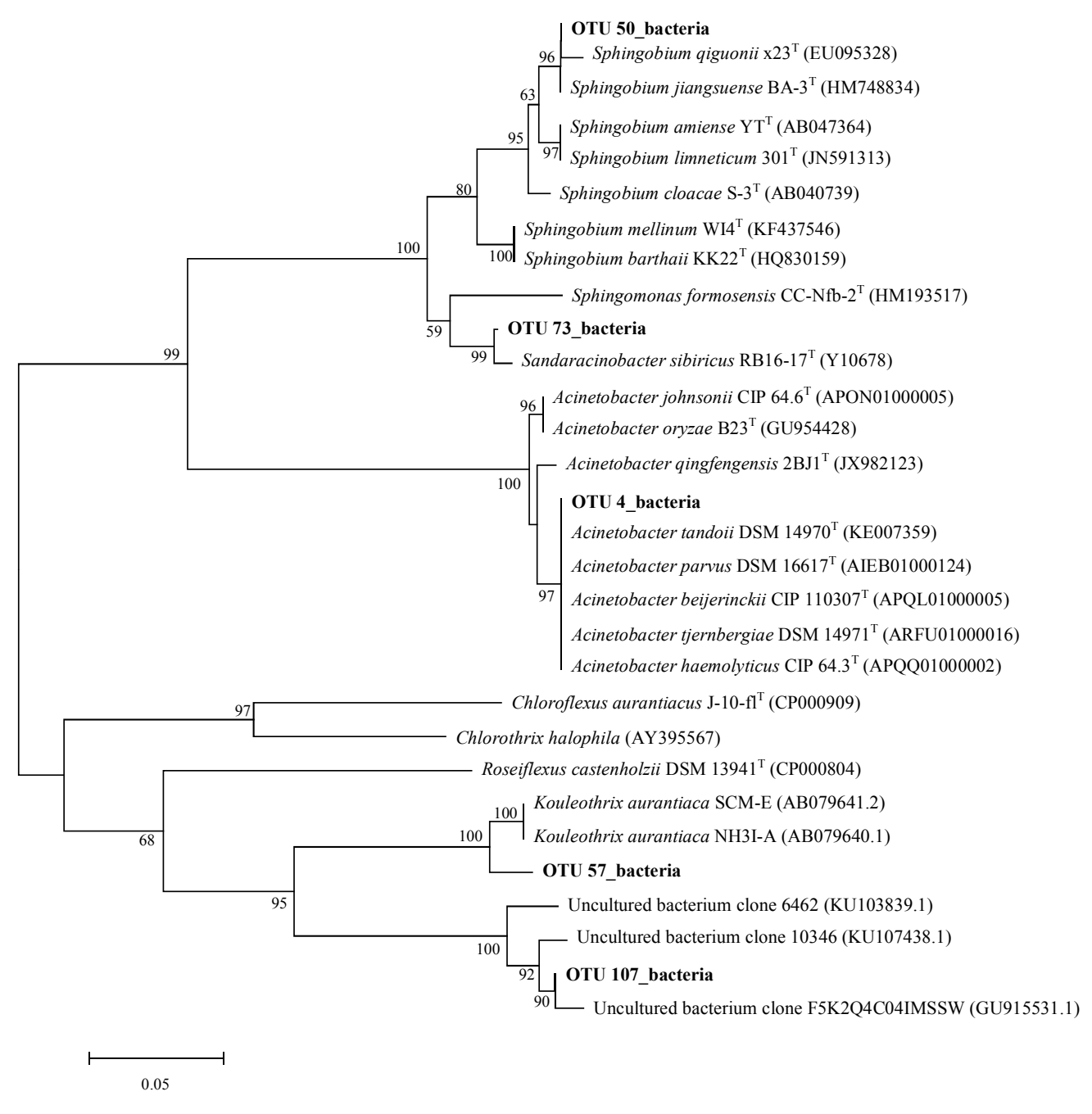

655 
$656 \quad$ Figure 3

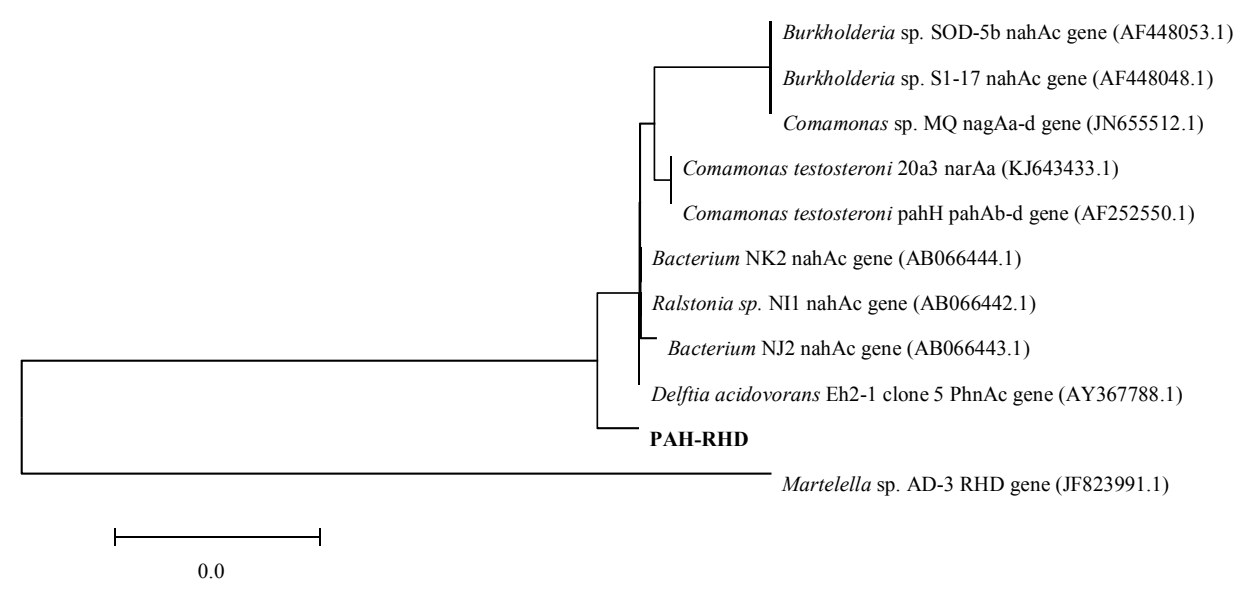

657

658 
$659 \quad$ Figure 4
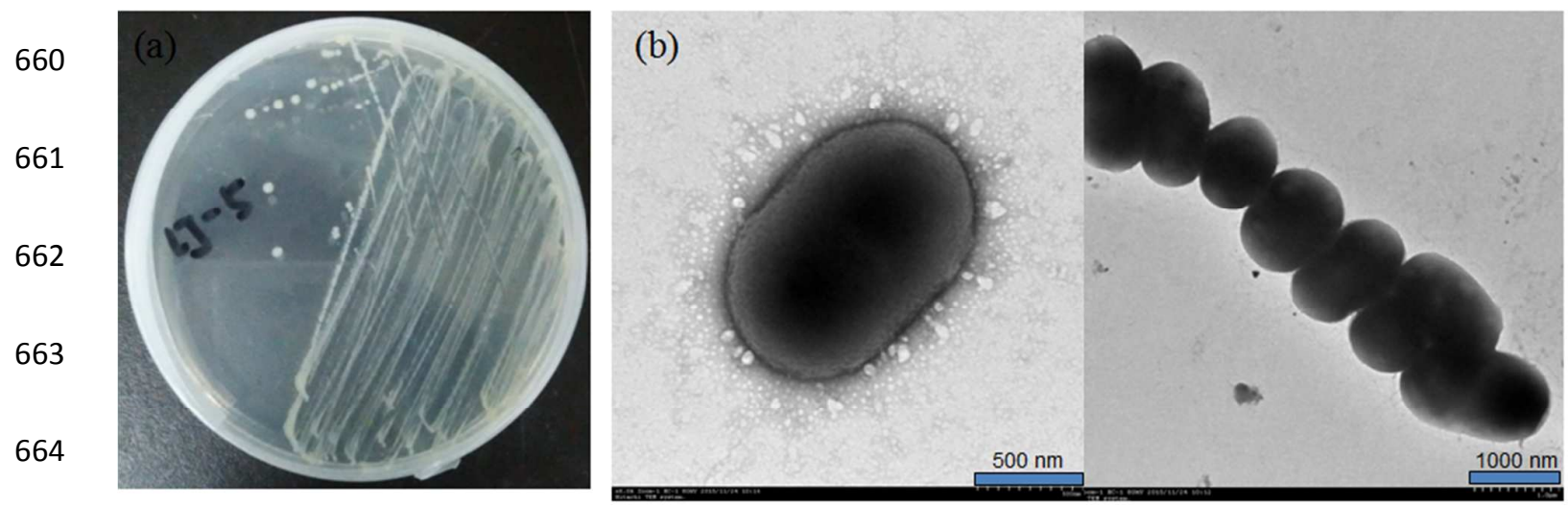

665

666 
$667 \quad$ Figure 5

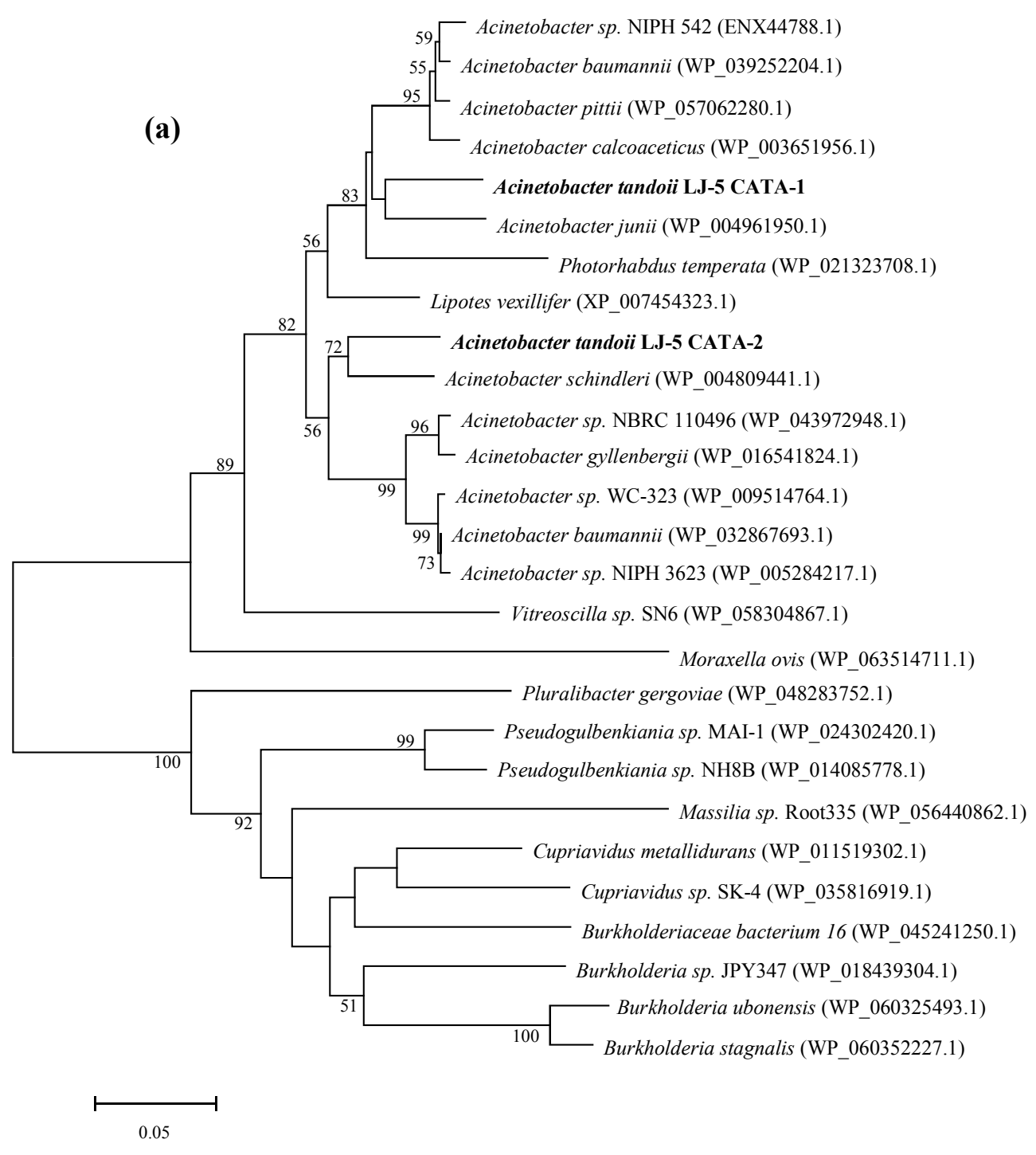




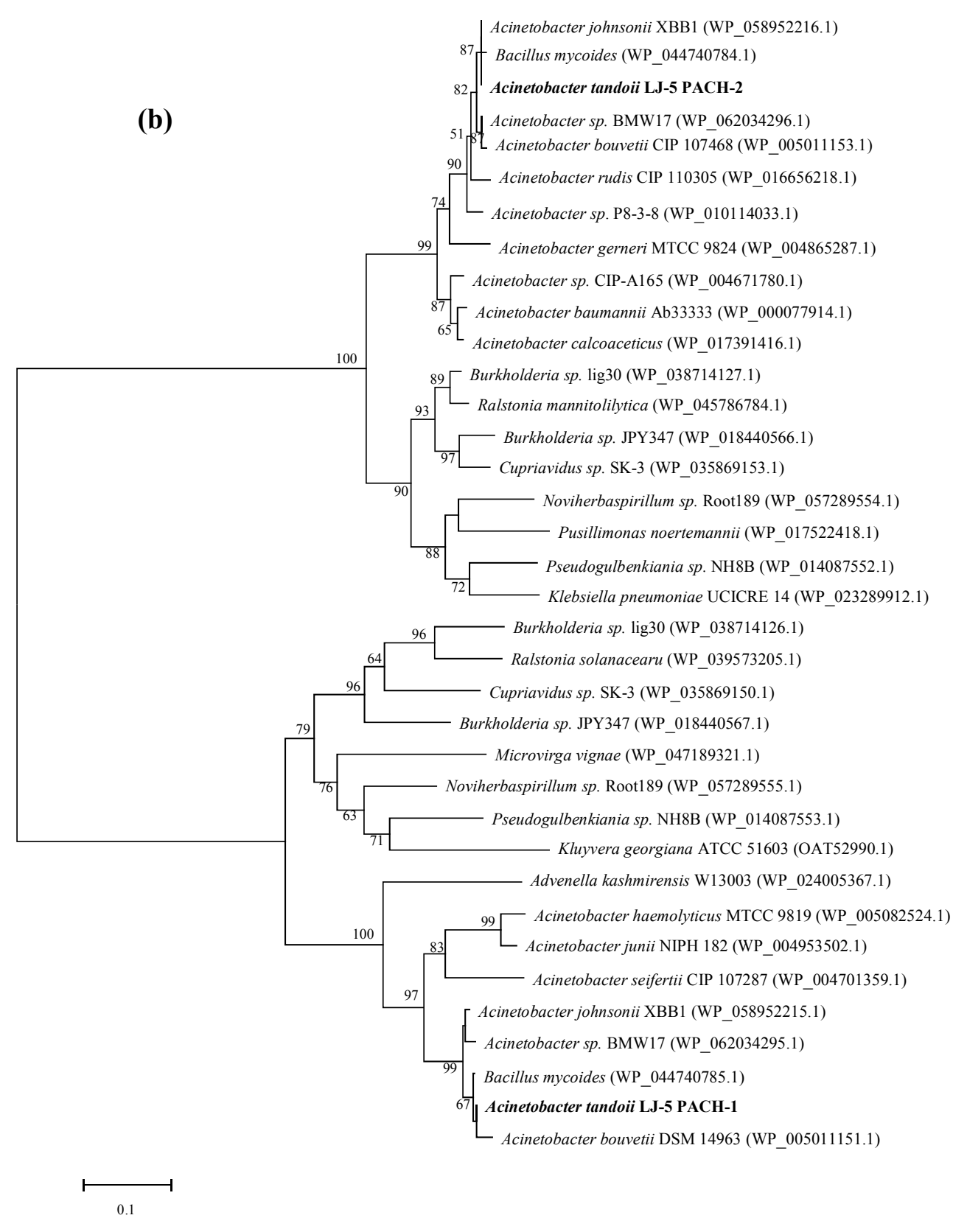

